\title{
The Students' Error in Using Conjunction (Because, Since, as, in Case) in the Sentences
}

\author{
Tagor Pangaribuan ${ }^{1}$, Elisa Haddina ${ }^{1} \&$ Sondang Manik ${ }^{1}$ \\ ${ }^{1}$ College of Ap Nommensen HKBP University, Medan, Indonesia \\ Correspondence: Tagor Pangaribuan, College of Ap Nommensen HKBP University, Medan, Indonesia. E-mail: \\ tagorbpphkbp@gmail.com
}

Received: February 18, 2018

Accepted: March 18, 2018 Online Published: March 20, 2018

doi: 10.5539/elt.v11n4p91

URL: http://doi.org/10.5539/elt.v11n4p91

\begin{abstract}
This research deals with the students' error in using conjunction (because, since, as, in case) in the sentences. Conjunction is very important for the learners to develop a skill in grammar. And grammar is the most important part of language for anyone. Should be first understood before being able to construct sentences, rules based on the grammar of language are used to express a certain idea represented in a sentence. By understanding the grammatical rules, the sentences can be arranged to produce the desired meaning. The objective of the study are to find out the students' difficulties in using subordinate conjunction and to find out the causes of the students' problems in using subordinate conjunction. Finding of the study expected to provide information for the improvement of teaching conjunction. In addition the findings and description would be of some use for the teachers in teaching conjunction. The outcomes would be useful in minimizing the difficulties in teaching conjunctions. The data of this research were the scores of the students based on the number of items that they hard correctly. A test was administered to collect the data; the research was helped by the classroom English teacher. Based on the value of standard reliability, the result of reliability of the test is 0.97 ; it means that the value of the standard reliability of test is very good. It was shown that students made more errors working with items numbers 5,6,9,10,14, and 15 the total frequency of errors were 237 all items. It means that the second students of Senior High School, SMK Swasta HKBP Pematangsiantar good errors in using subordinate conjunction (as, in, case, because, since) in the sentence (complex sentences).
\end{abstract}

Keywords: descriptive text, conjunction, student's error

\section{Introduction}

\subsection{The Background of the Study}

There are so many languages in Indonesia as there are ethnic groups where they use their own language. Human being can not be separated from language in communication in their life and of course, a lot of thing that want to be expressed in their communication between one people to another. A sentence is built on the basic of structural pattern containing word that expresses a certain meaning. Frank (1972) says: traditionally, word can be classified into eight parts of speech, such as: noun, pronoun, adjective, verb, adverb, conjunction, preposition, and interjection.

And grammar is one of the aspects of the teaching English. One part of grammar is conjunction. Conjunction is a word which merely joins together two words, phrases and sentences. Without this, every sentence will be short and unrelated to its neighbors and will take a long time to say everything. That sentences which are related to each other in meaning maybe combined using connection that indicated the relationship between the two sentences.

Conjunction is very important for the learners to develop a skill in grammar. And grammar is the most important part of language for anyone. Should be first understood before being able to construct sentences, rules based on the grammar of language are used to express a certain idea represented in a sentence. By understanding the grammatical rules, the sentences can be arranged to produce the desired meaning.

\subsection{The Scope of the Study}

The problems in this research were identified as, the students' error in using subordinate conjunction and the causes of the error in using subordinate conjunction. This research was focused on the students in using 
conjunction in the sentence. Especially the conjunction were ones know as subordinate conjunction (because, since, as, in case)

\subsection{The Objective of the Study}

The writer formulated the problem of this research as, do the students make error in using subordinate conjunction? And What are the causes of error in using subordinate conjunction?. Based on the formulated problem previously the objectives of this study are, The students' difficulties in using subordinate conjunction and to find out the causes of the students' problems in using subordinate conjunction.

\subsection{The Significance of the Study}

Finding of the study expected to provide information for the improvement of teaching conjunction. In addition the findings and description would be of some use for the teachers in teaching conjunction. The outcomes would be useful in minimizing the difficulties in teaching conjunctions.

\section{Research Design}

\subsection{Description of Conjunction}

Conjunction is a word that joins words or group of words, in addition, Greene (1973: 440) argue "A conjunction is a word that joins one part of a sentence with another". Those quotations show that a conjunction is a joiner that conjoins part of a sentence. Conjunction belongs to category of function words (pronoun, conjunction, preposition, and interjection). Which are primarily used to modify other parts speech or content words (noun, verb, adjective, and adverb).

\subsection{Types of Conjunction}

There are two types of conjunction, coordinate and subordinate conjunction. And in this case subordinate conjunction are because, since, as and in case.

\section{1) Coordinate Conjunction}

Wishon and Burks (1980) says that: "These conjunction equal sentence parts, the coordinate conjunction joins structural units and is grammatically independent of this unit. Coordinate units consisting of parts of speech, phrases, or clause may also be classified according to their function in the sentence:

(1) Compound subject:

1. Dogs and cats do not get along (Subject consist of nouns).

2. How much she buys for the clothes or where she buys them does not interest her husband (Subject consist of noun clause).

(2) Compound predicates:

They went for dinner but returned in time for favorite television program (Subject consist of verb and modifier).

(3) Compound objects:

1. He looked every where for his keys and wallet (Object of preposition consist of nouns).

2. He said that he was tired and that he was going to bed (direct object consist of noun clauses).

(4) Compound modifier:

1. He was tired but happy (modifier consist of adjectives).

2. The violinist played but dispassionately (modifier consist of adverbs).

3. Anyone who doesn't like the new policy of this company and who would like to resign to do so (modifier consist of adjective clauses).

\section{2) Subordinate Conjunctions}

According to Frank (1972) states "A subordinate conjunction introduce a clause that independent clause". The words used as subordinate conjunction are when, until, if, although, that, whatever, than, as, before, after, and since.

Wren and Martin (1990) state "Subordinate conjunction joins a clause another on which it depends for full meaning". The subordinate conjunctions include after, because, if, although, that, whether, than, though, till, before, and unless.

And Hartono (1996) states subordinate conjunction join a main clause with dependent clause". This way is called 
modes of defenses, which has nine kinds. They are apposition, cause or reason, result of effect, purpose or intention, condition, concession, comparison, time and the way or the level.

\section{Form of sentence}

\section{Simple sentences}

A simple sentence is one which has only one subject and one predicate or grammatical form which consists of only independent clause. In other words, it is composed only in one independent clause until now we have not all agreed on standard definition.

\section{Complex sentences}

A complex sentence consists of one main clause and one oe more subordinate clauses. Or in other words, a complex sentence sentence consits of one independent clause and one or more dependent clauses. The pendent clause can come in the middle of a complex sentence, as well as at the beginning or end.

\section{Compound sentence}

A compound sentence is grammatical from which consist of one or more independent clauses the express closely related ideas and each sentence can stand alone as simple sentence. The clauses of compound sentences may be joined together by coordinate conjunction ( and, but, or, and, nor,so,yet, correlative conjunctions (either, or,not only...but also) or conjunction adverbs (such as however, therefore, or consequently).

\section{Compound complex sentences}

A compound complex sentence is made up two or more independent clauses and one or more dependent clauses (subordinate clauses).

\section{Population and sample}

Determining the size of population to be investigated was one of the problems in doing a research. The population of research was the second year students of SMK Swasta HKBP Pematang Siantar in grade 2. There are five parallel classes, they are 110 students. In obtaining the sample, the researcher used random sampling technique. According to Arikunto (1989: 107) suggests that $10 \%-15 \%$ or $20 \%-25 \%$ or more as sample when the population is more than 100 is enough. And sample was taken out randomly from above five classes, taken 7 students for each class, so sample add up to 37 students from 150 students as population.

Population and Sample

\begin{tabular}{llll}
\hline No & Class & Population & Sample \\
\hline 1 & IIA Elec & 20 & 7 \\
2 & IIA Oto & 40 & 7 \\
3 & IIB Oto & 30 & 7 \\
4 & IIC Oto & 30 & 7 \\
5 & IID Oto & 30 & 7 \\
Total & & 150 & 37 \\
\hline
\end{tabular}

The Instrument of Research

The data collection was an important part in conducting a research. The data of study was collected by using the teacher's made test which to measure students' achievement to use conjunction (because, since, as, in case) in the sentences of multiple choice test.

The test was designed under the consideration of 1. Validity 2. Reliability. This was shown below:

\section{a. Validity}

Gurning (1994) says that four types of validity are used in educational and psychological measurement: construct, content, face, and criterion related validity. Construct validity is a hypothetical idea such as motivation, aggression, intelligence, or test anxiety. Content concerns how well the instrument measures the objectives or content of the variables studied in research problem. 


\section{b. Reliability}

Gurning (1995) says that reliability is estimated by correlating two or mare sets of measurements. The consistency or dependability or measure obtained from an instrument whose measures are consistent after time. This may mean dependability another part of from one from of an instrument to another from. Internal consistency can be estimated by split half technique or by one Kuder Richardsan formulas or Crosbachs Alpha.

\section{Technique of Data Analysis}

In analyzing the data, descriptive quantitative technique was used. In this technique, error analysis students based on the classification of conjunction then their problems were analyzed to find out the cause of the problems. The percentage calculation of the students in the data from the test, the percentage of the students' right or wrong answers were counted by the formula below:

$Q=\frac{N}{K} x 100 \%$

Notes:

Q: The percentage of the correct items.

$\mathrm{N}$ : The number of the correct answers.

$\mathrm{K}$ : The number of items.

\section{Data Analysis}

The data of this research were the scores of the students based on the number of items that they hard correctly. A test was administered to collect the data; the research was helped by the classroom English teacher.

Table 1. The scores of the students

\begin{tabular}{lllll}
\hline No & Students Initial & Correct & Error & Score \\
\hline 1 & AF & 20 & 0 & 20 \\
2 & AFD & 19 & 1 & 19 \\
3 & AS & 19 & 1 & 19 \\
4 & ASP & 16 & 4 & 16 \\
5 & AY & 16 & 4 & 16 \\
6 & AH & 17 & 3 & 17 \\
7 & AP & 18 & 2 & 18 \\
8 & AJ & 18 & 2 & 18 \\
9 & AST & 17 & 3 & 17 \\
10 & BG & 15 & 5 & 15 \\
11 & BR & 18 & 2 & 18 \\
12 & BU & 17 & 3 & 17 \\
13 & DS & 17 & 3 & 17 \\
14 & ES & 17 & 3 & 17 \\
15 & FI & 17 & 3 & 17 \\
16 & GS & 16 & 4 & 16 \\
17 & HFG & 13 & 7 & 13 \\
18 & HY & 13 & 7 & 13 \\
19 & HW & 13 & 7 & 13 \\
20 & ISP & 12 & 8 & 12 \\
21 & JS & 13 & 7 & 13 \\
\hline
\end{tabular}




\begin{tabular}{lllll}
\hline 22 & JW & 14 & 6 & 14 \\
23 & LH & 14 & 6 & 14 \\
24 & MRF & 13 & 7 & 13 \\
25 & MRA & 12 & 8 & 12 \\
26 & MRR & 10 & 10 & 10 \\
27 & MRA & 12 & 8 & 12 \\
28 & AI & 13 & 7 & 13 \\
29 & AMC & 15 & 5 & 15 \\
30 & AW & 7 & 13 & 7 \\
31 & AIU & 9 & 11 & 9 \\
32 & AT & 17 & 3 & 17 \\
33 & ASY & 16 & 4 & 16 \\
34 & BS & 15 & 5 & 13 \\
35 & BR & 14 & 6 & 14 \\
36 & CSO & 11 & 9 & 11 \\
37 & CU & 11 & 9 & 11 \\
38 & DI & 5 & 15 & 5 \\
39 & DH & 6 & 14 & 6 \\
40 & DHP & 8 & 12 & 8 \\
\hline
\end{tabular}

After the scores were obtained, then the regard data were analyzed by calculating errors of each student's scores, it can be seem in the table below.

Table 2. The students' error in using Subordinate conjunction

\begin{tabular}{lll}
\hline NO & Students Initial & Error \\
\hline 1 & AF & 0 \\
2 & AFD & 1 \\
3 & AS & 1 \\
4 & ASP & 4 \\
5 & AY & 4 \\
6 & AH & 3 \\
7 & AP & 2 \\
8 & AJ & 2 \\
9 & AST & 3 \\
10 & BG & 5 \\
11 & BR & 2 \\
12 & BU & 3 \\
13 & DS & 3 \\
14 & ES & 3 \\
15 & FI & 3 \\
16 & GS & 4 \\
17 & HFG & 7 \\
\hline
\end{tabular}




\begin{tabular}{lll}
\hline 18 & HY & 7 \\
19 & HW & 7 \\
20 & ISP & 8 \\
21 & JS & 7 \\
22 & JW & 6 \\
23 & LH & 6 \\
24 & MRF & 7 \\
25 & MRA & 8 \\
26 & MRR & 10 \\
27 & MRA & 8 \\
28 & AI & 7 \\
29 & AMC & 5 \\
30 & AW & 13 \\
31 & AIU & 11 \\
32 & AT & 3 \\
33 & ASY & 4 \\
34 & BS & 5 \\
35 & BR & 6 \\
36 & CSO & 9 \\
37 & CU & 9 \\
38 & DI & 15 \\
39 & DH & 14 \\
40 & DHP & 12 \\
\hline
\end{tabular}

Based on the result of the Data analysis above, specifically the students' error in using subordinate conjuction could be analyzed per item of the test, It was done to know which item was often wrongly answered by the students, specification of error analysis could be seen as the following table.

Table 3. The students' error per item of test

\begin{tabular}{ll}
\hline No Item & Error of each Item \\
\hline 1 & 7 \\
2 & 8 \\
3 & 12 \\
4 & 11 \\
5 & 17 \\
6 & 17 \\
7 & 8 \\
8 & 8 \\
9 & 17 \\
10 & 17 \\
11 & 14 \\
12 & 8 \\
\hline
\end{tabular}




\begin{tabular}{ll}
\hline 13 & 9 \\
14 & 17 \\
15 & 16 \\
16 & 9 \\
17 & 9 \\
18 & 10 \\
19 & 10 \\
20 & 13 \\
Total & 237 \\
\hline
\end{tabular}

Table 4. The causes and the types of error in using subordinate conjunction

\begin{tabular}{lllllll}
\hline $\begin{array}{l}\text { Subordinate } \\
\text { Conjunction }\end{array}$ & $\begin{array}{l}\text { Frequency } \\
\text { of errors }\end{array}$ & Intralingual & Interlingual & Crelessness & $\begin{array}{l}\text { Type } \\
\text { error } \\
\text { this } \\
\text { research }\end{array}$ & $\begin{array}{l}\text { of Type of error } \\
\text { in }\end{array}$ \\
\hline As & 83 & $\checkmark$ & $\checkmark$ & (st) & Addition (ad) \\
Since & 33 & $\checkmark$ & $\checkmark$ & (st) & Omission (om) \\
In case & 77 & & $\checkmark$ & (st) & Subsitution (st) \\
Because & 44 & & $\checkmark$ & (st) & Reordering (rc) \\
Total & 237 & 2 & 4 & & \\
\hline
\end{tabular}

\subsection{Validity of the Test}

The researcher arranged the material such away so that the test would be representative enough to measure to students' error and causes of error in using subordinate conjunction in the sentence. According to Suharsimi Arikunto (2002) "An instrument is valid if it measure what is purposed". In arranging and analyzing the material of the test. The material arranged in such as a way, so that test would be respected enough to analyze the students' error and causes in using subordinate conjunction (since, in case, as, because).

Table 5 . The calculation of validity of the test

\begin{tabular}{lllllll}
\hline No & $\mathrm{X}$ & No & $\mathrm{Y}$ & $\mathrm{X}^{2}$ & $\mathrm{Y}^{2}$ & $\mathrm{XY}$ \\
\hline 1 & 20 & 2 & 19 & 400 & 361 & 380 \\
3 & 19 & 4 & 16 & 361 & 256 & 304 \\
5 & 16 & 6 & 17 & 256 & 289 & 272 \\
7 & 18 & 8 & 18 & 324 & 324 & 324 \\
9 & 17 & 10 & 15 & 289 & 225 & 255 \\
11 & 18 & 12 & 17 & 324 & 289 & 306 \\
13 & 17 & 14 & 17 & 289 & 289 & 289 \\
15 & 17 & 16 & 16 & 289 & 256 & 272 \\
17 & 13 & 18 & 13 & 169 & 169 & 169 \\
19 & 13 & 20 & 12 & 169 & 144 & 156 \\
21 & 13 & 22 & 14 & 169 & 196 & 182 \\
23 & 14 & 24 & 13 & 196 & 169 & 182 \\
25 & 12 & 26 & 10 & 144 & 100 & 120 \\
27 & 12 & 28 & 13 & 144 & 169 & 156 \\
\hline
\end{tabular}




\begin{tabular}{lllllll}
\hline 29 & 15 & 30 & 7 & 225 & 49 & 105 \\
31 & 9 & 32 & 7 & 225 & 49 & 105 \\
33 & 16 & 34 & 15 & 256 & 225 & 240 \\
35 & 14 & 36 & 11 & 196 & 121 & 154 \\
37 & 11 & 38 & 5 & 121 & 25 & 55 \\
39 & 6 & 40 & 8 & 36 & 64 & 48 \\
Total & $\sum 290$ & & $\sum 273$ & $\sum 4438$ & $\sum 4009$ & $\sum 4122$ \\
\hline
\end{tabular}

$$
\begin{aligned}
r_{x y} & =\frac{N\left(\sum X Y\right)-\left(\sum X\right)\left(\sum Y\right)}{\sqrt{\left.\left\{N \sum X^{2}-\left(\sum x\right)^{2}\right\} N\left(\sum Y^{2}-\sum Y\right)^{2}\right\}}} \\
r_{x y} & =\frac{40(4122)-(290)(273)}{\left.\left.\sqrt{\left\{40 x 4438-(290)^{2}\right.}\right\} 40 x 4009-(273)^{2}\right\}} \\
r_{x y} & =\frac{164880-79170}{\sqrt{(93420)(85831)}} \\
r_{x y} & =\frac{85710}{89545.13957} \\
& =0.957170879 \\
& =0.95
\end{aligned}
$$

Note:

$\mathrm{N} \quad=$ The total number of Students

rxy $=$ The Coefficient of Product Moment Correlation of the test

Arikunto's correlation formula is applied (1993) recommended that the value of the validity is as follow :

$0.00-0.20 \quad:$ had no correlation (the test is not valid)

$0.21-040 \quad$ : low correlation (the test is low validity)

$0.41-0.60$ : fair correlation (the test is fair validity)

$0.61-0.80 \quad:$ high correlation (the test is high validity)

$0.81-1.00 \quad$ : Complete (the test is complete validity)

Based on the standard validity above then the result of validity of the test is 0.95 it means that test is "Complete validity'.

\subsection{Reliability of the Test}

Harris (1997) says that "Reliability is the ability of the test scores. A test can not measure anything well unless it measures consistently. To have confidences in measuring instrument, we would need to be assured by using the following computation:

$$
\begin{aligned}
& \mathrm{R}=\frac{2 . r x y}{1+r x y} \\
& \mathrm{R}=\frac{2.0 .95}{1+0.95} \\
& \mathrm{R}=\frac{1.9}{1.95} \\
& \mathrm{R}=0.97358974 \\
& \mathrm{R}=0.97
\end{aligned}
$$


Based on the value of standard reliability above, the result of reliability of the test is 0.97 ; it means that the value of the standard reliability of test is very good.

The value of standard reliability is as follows:

$0.00-0.20 \quad:$ the reliability standard is empty

$0.21-040 \quad$ : the reliability standard is low

$0.41-0.60 \quad$ : the reliability standard is fair

$0.61-0.80 \quad$ : the reliability standard is good

$0.81-1.00 \quad$ : the reliability standard is very good

\section{Conclusion}

After analyzing the data, the conclusions can be drawn as follows:

1) It was shown that students made errors in using subordinate conjunction (since, in case, as, because) in complex sentences.

2) It was shown that students made more errors working with items numbers $5,6,9,10,14$, and 15 the total frequency of errors were 237 all items. It means that the second students of Senior High school SMK Swasta HKBP Pematang Siantar, good errors in using subordinate conjunction (as, in, case, because, since) in the sentence (complex sentences).

3) It was found that most of the students got errors in answering items number 5, 6, 9,10,14, and 15 . For number 5 and 10 it dealt with the use of subordinate number 6,9 and 15, it concerned with the use of subordinate conjunction "in case" which was typically caused by carelessness or context. For number 14, it dealt with the use of subordinate conjunction "since" which was typically caused by interlingual and carelessness. And then students got more errors in using subordinate conjunction "as" in complex sentences. There were 83 frequencies of errors.

4) Type of errors that the students made was "substitution" (It is a sentence which of it is aspects (Word) is substituted by another). Students made errors were caused more by carelessness rather that by interlingual.

5) There were two subordinate conjunctions of four (since, as, because, in case) in errors caused by interlingual cause, they are "as" and "since". Most of students transferred both these conjunctions into Indonesia translation so that they got errors to use, in addition to both they have more that one meaning. There were all subordinate conjunctions (since, in case, because) caused by carelessness or students got errors in using them contextually.

\section{References}

Ali, A. Y. (1993). The Holy Qur'an Translation and Commentary. Maryland: Amana.

Arikunto. (1986). Dasar-dasar Evaluasi Kependidikan.Jakarta: Bima Angkasa.

Burt, M., \& Finochiaro, D. (1997). View Points on English as Second Language. America.

Frank, M. (1972). Modern English, A Practical Reference Guide. New Jersey: Prentice Hall.

Gianto, A. C. (1983). Konjungsi, dan, atau, tetapi. Yogyakarta: Kanisius.

Gurning, B. (1999). Media Pendidikan. Medan: IKIP Press.

Hamalik, O. (1989). Media Pendidikan. Bandung: Alumni.

Hartanto, J. S. (1996). Accurate, Brief, and Clear English Grammar. Surabaya: Indah.

Khairil. (2003). English Structure. Medan: UMSU (Unpublished).

Khron, R. (1986). English Sentence Structure. U.S.A: The University of Mechigan.

Murphy, R. (1985). English Grammar in Use. Australia: Cambridge University.

Puspa, Y. P. (1990). Principal English Grammar. Semarang: Aneka Ilmu.

Tim, P. (2000). Pedomon Penulisan Skripsi dan Ujian Skripsi. Medan FKIP: UMSU (Unpublished).

Wardaugh, R. (1972). Introduction to Linguistics. USA: University of Michigan.

Webster, M. (1984). Longman Dictionary of The English Language. London: Becless.

Wishon, G. E., \& Burks, J. M. (1980). Lets Write English. America: Revised Edition.

Wren \& Martin. (1990). High School English Grammar and Composition. New Delhi: Prasada. 


\section{Copyrights}

Copyright for this article is retained by the author(s), with first publication rights granted to the journal.

This is an open-access article distributed under the terms and conditions of the Creative Commons Attribution license (http://creativecommons.org/licenses/by/4.0/). 